\title{
An iconic messenger of climate change? Predicting the range dynamics of the European Bee-eater (Merops apiaster)
}

\author{
Darius Stiels $^{1} \cdot$ Hans-Valentin Bastian ${ }^{2} \cdot$ Anita Bastian $^{2} \cdot$ Kathrin Schidelko $^{1} \cdot$ Jan O. Engler ${ }^{3,4}$ (D)
}

Received: 24 August 2020 / Revised: 14 January 2021 / Accepted: 12 February 2021 / Published online: 18 March 2021

(c) The Author(s) 2021

\begin{abstract}
When environmental conditions change, species usually face three options: adaptation, range shifts, or extinction. In the wake of climate change, it is generally believed that range shifts are the norm in mobile species such as birds, resulting in poleward range shifts. The European Bee-eater is a predominantly Mediterranean species which has expanded its range to higher latitudes over the last decades. Germany in particular has seen a surge in breeding pairs and foundation of new colonies. However, while many experts suggest climate warming as the main driver behind this range expansion, an explicit quantification remains open. Here, we use an ensemble modelling approach to study the recent climatic niche suitability of the European Bee-eater across Europe with a special focus on Germany and project its predicted Palaearctic breeding distribution onto the year 2050 using two global circulation models and two representative concentration pathways. Models were able to predict the current European range of the species with some underestimated areas in Central and Eastern Europe, depending on the selected model. We found a strong relationship between climatic suitable areas and estimated population sizes across European countries that is reflected in most algorithms. In particular, the German population size is in line with climate suitability in the country suggesting a strong climate-population relationship and a high degree of niche filling. Most future predictions point to an ongoing northward expansion of the species while areas in Southern Europe and the Maghreb area remain largely suitable. The strong climate-population relationship makes the European Bee-eater an appropriate indicator species for climate change. Yet the high variability of modelling algorithms also call for caution of using these techniques without careful inspection.
\end{abstract}

Keywords Climate change $\cdot$ Birds $\cdot$ Meropidae $\cdot$ Range shift $\cdot$ Distribution $\cdot$ Abundance

\section{Zusammenfassung}

Ein Indikator des Klimawandels? Vorhersagen zur Verbreitungsdynamik des Bienenfressers (Merops apiaster) Wenn sich Umweltbedingungen ändern, haben Arten drei Möglichkeiten zu reagieren: Anpassung, Verbreitungsveränderungen oder Aussterben. Der Klimawandel bewirkt bei mobilen Arten wie Vögeln in den gemäßigten Breiten in der Regel eine polwärts gerichtete Verschiebung des Verbreitungsgebietes. Der Bienenfresser ist in Europa eine überwiegend mediterrane Art, die in den letzten Jahrzehnten ihre Verbreitung nach Mitteleuropa ausdehnen konnte. Besonders in Deutschland konnte der Bienenfresser im Bestand zunehmen und neue Kolonien gründen. Zwar wird das Klima als Hauptverursacher der beobachteten Ausbreitung angenommen, eine genaue Quantifizierung der Zusammenhänge fehlt jedoch bisher. Wir nutzen

Communicated by T. Gottschalk.

Jan O. Engler

Jan_Oliver.Engler@tu-dresden.de

1 Section of Ornithology, Zoological Research Museum Alexander Koenig, Adenauerallee 160, 53113 Bonn, Germany

2 Special Interest Group "European Bee-Eater" of the German Ornithologists' Society, Geschwister-Scholl-Straße 15,

D-67304 Kerzenheim, Germany
3 Terrestrial Ecology Unit, Ghent University, K.L. Ledeganckstraat 35, B-9000 Ghent, Belgium

4 Chair of Computational Landscape Ecology, Technische Universität Dresden, Helmholtzstraße 10, 01069 Dresden, Germany 
daher einen Ensemble-Modell-Ansatz, um die Klimaeignung des Bienenfressers in Europa und speziell in Deutschland zu überprüfen und projizieren die Modelle auf die Klimabedingungen des Jahres 2050 basierend auf zwei globalen Zirkulationsmodellen und zwei repräsentativen Konzentrationspfaden. Die Modelle sind geeignet, die europäische Verbreitung der Art vorherzusagen, wobei es je nach Modell aber auch zu Unterschätzungen, vor allem in Mittel- und Osteuropa, kommen kann. Die meisten Algorithmen zeigen einen starken Zusammenhang zwischen der klimatisch geeigneten Fläche und der Brutpopulation des Bienenfressers für die meisten europäischen Länder. Auch in Deutschland lässt sich die Größe der hiesigen Bienenfresserpopulation durch die Fläche mit geeigneten Klimabedingungen erklären, was auf eine deutliche Nischenfüllung hindeutet. Die meisten Zukunftsprojektionen weisen auf eine weitere nordwärts gerichtete Ausbreitung hin, während Gebiete in Südeuropa und dem Maghreb größtenteils weiterhin klimatisch geeignet bleiben. Aufgrund des starken Zusammenhangs zwischen Klimaeignung und Populationsgröße schlussfolgern wir, dass der Bienenfresser eine geeignete Indikatorart für den Klimawandel ist, weisen aber auch auf die Variation in den Ergebnissen unterschiedlicher Modelle hin.

\section{Introduction}

Changes of environmental conditions make species usually react in three non-exclusive ways: evolutionary adaptation, range shifts or extinction. For species with potentially high dispersal abilities, such as birds, range shifts are believed to be the norm in the wake of climate change. As a consequence, breeding ranges of species in higher latitudes may shift polewards (Thomas and Lennon 1999; Parmesan and Yohe 2003; Hickling et al. 2006; Thomas 2010) or upwards along elevational gradients (Chen et al. 2011; Freeman et al. 2018). Both effects are tantamount with the assumption that species are able to track their climatic niches over time. Niche tracking can be observed over different time scales, ranging from intra-annual variation of seasonal niches up to niche conservatism across phylogenetic timescales (Peterson 2011; Engler et al. 2017). Nevertheless, while a growing number of studies support the assumption of niche tracking in response to climate change (e.g. Araújo et al. 2005; Tingley et al. 2009; La Sorte and Jetz 2012; Monahan and Tingley 2012), the question whether niche tracking is the norm is still unresolved (Engler et al. 2017). This is because even highly mobile species might be restricted in their dispersal capacities and track their niches only after a certain time lag (Devictor et al. 2008).

The European Bee-eater Merops apiaster is a turanianmediterranean faunal element which mainly breeds in the southwestern Palaearctic region in mediterranean, steppe and desert zones (Voous 1960; Fry and Boesman 2020). As long-distance migrants European Bee-eaters spend the northern winter in the Afrotropical region, mainly in western and southern Africa (e.g. Fry 2001). While the species also breeds in Namibia and South Africa (Fry 1988), we focus on the European breeding distribution of the species where it has shown a remarkable ongoing range expansion over the last decades at its northern range edge in Central and Western European countries such as Germany, Switzerland, France, Poland or Slovakia (e.g. Glutz von Blotzheim and Bauer 1980; Krištín and Kaňuch 2005; Gerber et al. 2011; Gedeon et al. 2014; Essel et al. 2016). Due to its excellent data coverage and its representative status as recently populated area, Germany will be in particular focus of our analysis. European Bee-eaters often breed in colonies and are generally inhabitants of open landscapes including agricultural land and river valleys (Voous 1960; Cramp 1985). The birds burrow nests in bare ground, often in banks, scarps and embankments, but also choose secondary habitats like quarries for breeding (Cramp 1985; Bauer et al. 2005). Most of these habitat types are locally exposed to warmer microclimates (e.g. Heneberg and Šimeček 2004).

While species' ranges are often related to climatic factors on a large scale (Pearson and Dawson 2003; Pigot et al. 2010), this could be particularly evident in the European Bee-eater. European bird species with a southern range centroid are often regarded as climate change indicators under global warming (Gregory et al. 2009). Moreover, trends of common bird species are related to their climate niche characteristics (Jiguet et al. 2010) offering a role for precipitation and temperature as driver of population change in Mediterranean birds (Herrando et al. 2019). Indeed, current and past range shifts in the European Bee-eater have been related to climate change (Kinzelbach et al. 1997; Reif et al. 2010), and the species has been called a 'flagship species for a northward range extension of a southerly distributed bird species in Europe' (Fiedler 2016). However, an explicit quantification of the relationship between the current range expansion of the European Bee-eater and climatic factors issurprisingly-lacking. Even more so, other factors than climate might affect southern species which extend their ranges into Central Europe. For example, the range extension of the Melodious Warbler Hippolais polyglotta might at least partially be explained by biotic interactions with its sister species, the Icterine Warbler Hippolais icterina (Engler et al. 2013). Other southerly distributed species like the Great White Egret Ardea alba showed an increase in abundance in Central Europe, most likely due to a combined effect of habitat change, the cessation of persecution, conservation measures and climate change (Eawicki 2014). Disentangling the interplay of different factors for 
the European Bee-eater hence requires a detailed analysis of climate-occurrence relationships.

We apply a set of species distribution models (SDMs) within an ensemble approach to: (1) study the current climatic niche suitability of European Bee-eaters across their Western Palearctic breeding range and (2) project its breeding distribution onto presumed climatic conditions of the year 2050 using two global circulation models (GCM) and two representative concentration pathways (RCP) of greenhouse gases. Over the last two decades, species distribution models have become a major tool for forecasting ranges of birds and other taxa (Guisan and Thuiller 2005; Elith et al. 2006; Elith and Leathwick 2009; Engler et al. 2017), although their application for range shifting species remains challenging (Elith et al. 2010). A special case of SDMs is ensemble models in which possible uncertainties of single SDMs are counterbalanced by combining multiple algorithms (Thuiller 2003; Araújo and New 2007). Moreover, SDMs were successfully applied to infer population dynamics such as species abundance allowing to quantify possible functional relationships of species with their environment (VanDerWal et al 2009; Thuiller et al. 2014; see Engler et al. 2017 for an exhaustive overview in birds). Herein, we present and compare results of eight different SDM algorithms used to quantify current climate-population relationships and predict the future range of the European Bee-eater. Specifically, we analyse whether climate models cover the current breeding range of the species and whether areas of niche unfilling at the northern range edge are prevalent. We assume that current population sizes in Europe are closely related to climatically suitable areas. Our objective is to test if the population size of the European Bee-eater in Germany follows this assumed relationship with climatic suitability. If the prediction of the correlation is correct, the observations will be close to the fit (Fig. 1, case B). Alternatively, higher or lower suitable areas than expected by the current population size would point to factors different from climate as a main driver of population dynamics, such as niche expansion (Fig. 1, case A) or lack of habitat or food resources (Fig. 1, case C). By applying future predictions, we want to know whether the northward shift of the species' range continues and whether this is accompanied by a range contraction at the southern range of its distribution.

\section{Material and methods}

\section{Species records}

We used two sources of occurrence data to achieve a broad coverage of the palaearctic breeding range of the European Bee-eater Merops apiaster, the Global Biodiversity

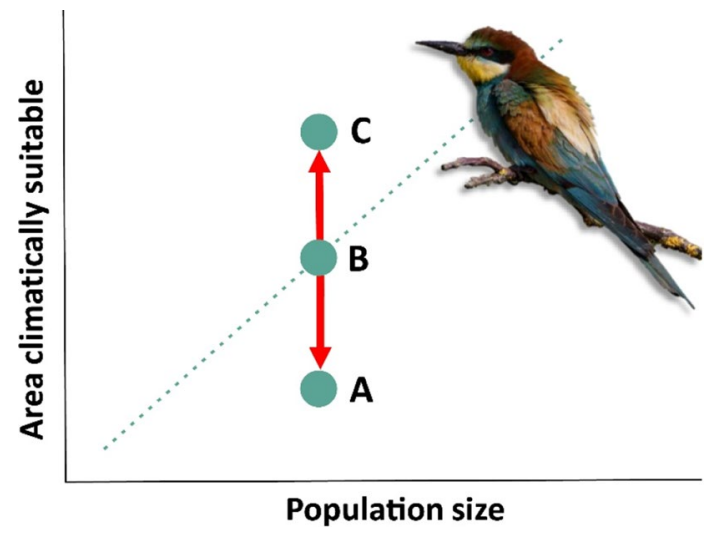

Fig. 1 We generally expect a strong positive correlation between suitable area ( $y$-axis) and population size ( $x$-axis) as the basis for the range expansion of European Bee-eaters with climate change (case B). If a region or country has strongly deviating residuals (cases A and C), European Bee-eaters follow other factors rather than climate

Information Facility (GBIF) and a database on distribution and population size of German breeding colonies. Specifically, we collected (1) georeferenced species data from GBIF (https://doi.org/10.15468/dl.4tjk09, last access 04.09.2019). We included "preserved specimens" and "human observations" from the core breeding season (i.e. June and July) to exclude most transients as well as vagrants out of their regular breeding area. To reduce sampling bias in presence records (Fourcade et al. 2014a), we filtered records using a grid of $10^{\circ}$ by randomly picking one record per grid cell. Moreover, we excluded any data outside the time frame 1979-2013 so that environmental and species data are in congruence (see below). While we focus on the European breeding distribution of our species, we also include occurrences from the eastern part of the range to improve niche estimations (Barbet-Massin et al. 2010). We limit records to a rectangle from $18^{\circ}$ western longitude to $100^{\circ}$ eastern longitude and $20^{\circ}-66^{\circ}$ northern latitude. Note, that we only infer predictions for currently inhabited ecoregions further restricting our study area (see below). (2) Since the GBIF dataset showed some geographical gaps at the northern and western distribution in Central Europe, we took additional occurrences of breeding colonies from the extensive database of the "Special Interest Group European Bee-eater" of the German Ornithologists' Society (H.-V. and A. Bastian, unpublished data). To the best of our knowledge, these data represent a nearly complete coverage of the breeding distribution of European Bee-eaters in Western, Southern, and Central Europe. In sum, we used 1382 unique occurrences for further analyses (Fig. 2). 


\section{Environmental data}

We used high-resolution climate data available through the CHELSA V1.2 database (www.chelsa-climate.org; Karger et al. (2017a, b)). We restricted the climate data to the months May to September to cover the breeding season of the species in the Western Palearctic. Based on monthly data of this five-month period, we created six predictor variables which are largely analogous to the familiar so-called bioclimatic variables (Hijmans et al. 2005): minimum temperature, maximum temperature, average temperature, precipitation sum, precipitation of the wettest month, and precipitation of the driest month. Present climate covers the time period 1979-2013. For future predictions, we applied four climate change scenarios for the year 2050 based on two different widely used climate global circulation models (GCMs: CCSM4 and MIROC5) and two representative concentration pathways (RCP 4.5 and 8.5). While RCP 4.5 represents an intermediate assumption, RCP 8.5 can be described as a very high emission scenario (IPCC 2014).

\section{Modelling}

We applied an ensemble modelling approach using eight different SDM algorithms as implemented in the Biomod2 R package (based on Biomod, Thuiller et al. 2009) including generalized linear models (GLM), generalized boosted models (GBM), random forests (RF), classification tree analysis (CTA), multivariate adaptive regression splines (MARS), artificial neural networks (ANN), flexible discriminant analysis (FDA), and the maximum entropy approach according to Phillips et al. (2006); i.e. MAXENT.Phillips; see Thuiller et al. (2009) for details). As model parameterization needs to be within an ecologically meaningful context (Guisan et al. 2014), we generated 10,000 random background records in ecoregions covered by $>95 \%$ of European Bee-eater presence records during the breeding season (Fig. 2). We excluded ecoregions with fewer records, because the species breeds in river valleys in deserts or other specific microhabitats which are not well covered by climate data and are hence likely to bias predictions. We extracted ecoregion information from the WWF Terrestrial Ecoregion map (Olson et al. 2001, available through https://www.worldwildlife. org/publications/terrestrial-ecoregions-of-the-world). In particular, we used the 'randomPoints' function in the dismo R package (Hijmans et al. 2016) that allows for a latitudinal correction since the environmental layers are not in a planar coordinate system resulting in a projection bias towards higher latitudes (Hijmans et al. 2016). We ran each algorithm 10 times, randomly keeping $30 \%$ of presence records for model testing in each iteration. We

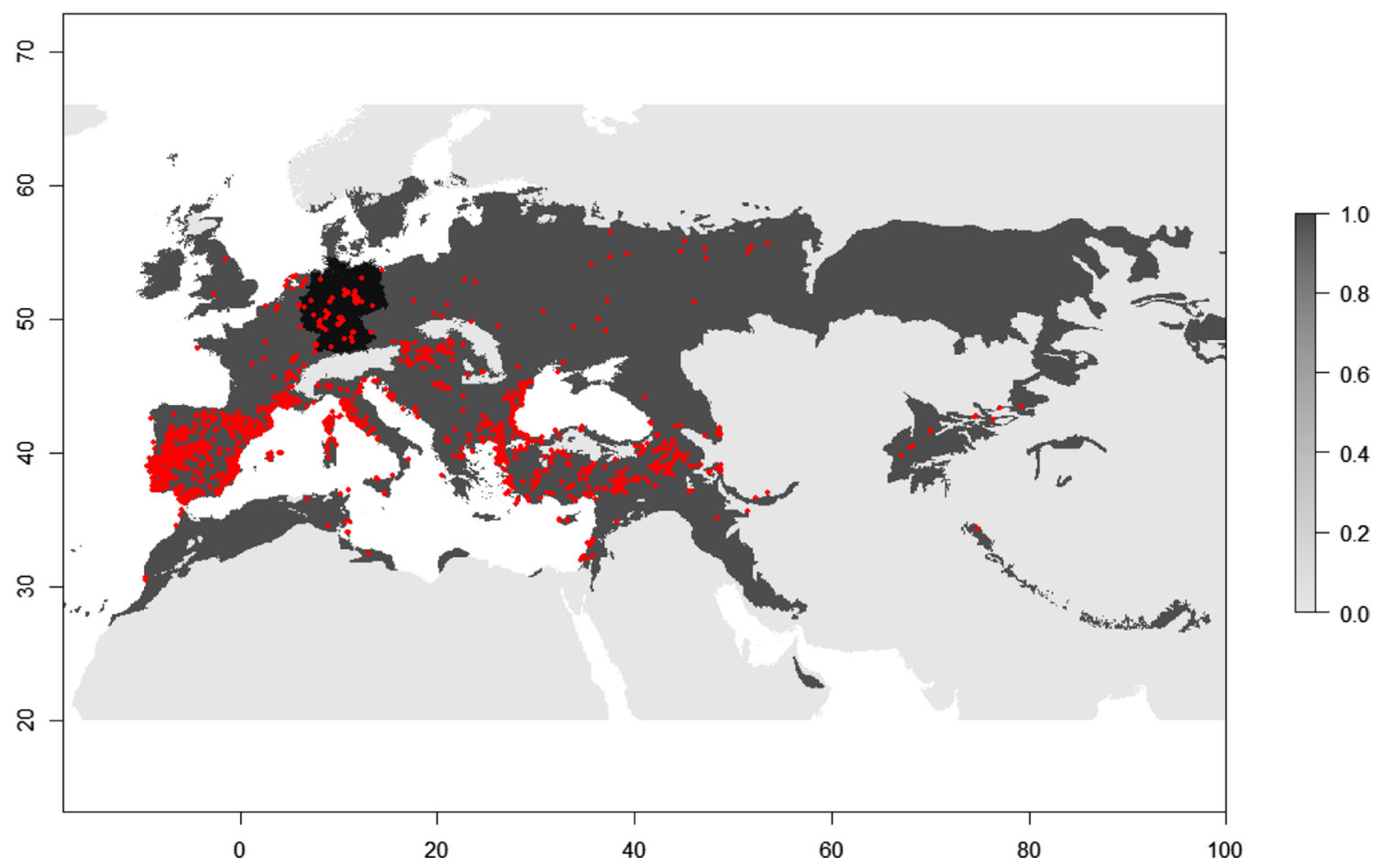

Fig. 2 Overview of the study area with the background (dark grey) covering ecoregions incorporating $95 \%$ of species records (red) during the breeding period. To test the role of climate-driven north-

ward range expansion, we focus on Germany (dark shade) where an exhaustive monitoring of breeding Bee-eaters is in place 
left all other model settings at default mode apart from rescaling predicted occurrence probabilities from $0-1$ to a 0-1000 integer scale for memory saving. For model quality assessment, we used the Area Under the Curve (AUC) of the receiver operating curve (ROC, Fielding and Bell 1997) and true skill statistic (TSS, Allouche et al. 2006) classification as evaluation metrics. We ensembled models for each algorithm separately applying a TSS threshold of 0.5 and using committee averaging. This allowed us to quantify algorithm-specific differences while applying the same quality criteria. To restrict for possible extrapolation errors in the predictions, we clipped areas outside the ecoregions chosen as background (see Guisan et al. 2014 and above) and used MESS maps (Elith et al. 2010) to clip areas of non-analogous climate in the dismo $\mathrm{R}$ package. We finally converted predictions into binary presenceabsence maps, using the maximum sum of sensitivity and specificity thresholds among all algorithms as performed in Biomod2. We ultimately stacked the batch of maps for each scenario into consensus maps.

\section{Country-level analyses}

To elaborate the general relationship between the climatically suitable area and population size, we first compiled information on country-level estimates of breeding populations of European Bee-Eaters (BirdLife International 2015). In particular, we selected country-level information with 'good' or 'medium' quality ranks while discarding country-level information ranked as 'poor'. This way, we gathered information from 20 countries. For these countries, we calculated the number of suitable cells for each SDM algorithm (i.e. cells with suitability score $>$ threshold) based on the current climate. Given that values in both predictors stretch across several orders of magnitude, we $\log (x+1)$ transformed each before including them in linear models to assess the strength of relationship for each SDM algorithm. Using the predict() function in $\mathrm{R}$, we estimated confidence intervals to check if the position of the German population in that relationship deviates strongly in either one or the other direction (Fig. 1).

\section{Results}

\section{Model performance}

According to a summary of statistical parameters, all model algorithms performed well with AUC values above 0.8 and TSS values above 0.5 (Table 1). Minimum precipitation had a consistently high variable importance across all algorithms. Likewise, mean temperature was ranked high for six out of eight algorithms where it was also ranked highest among all predictors. In the two algorithms (i.e. GBM and MAXENT) that considered the mean temperature less important, minimum temperature became critical (Table 1).

\section{Current potential distribution}

The European distribution of the European Bee-eater is well covered by the stacked summary map, and population

Table 1 Summary statistics of model performance (mean \pm sd) for 8 algorithms across 10 iterations and their respective ensembles.

\begin{tabular}{|c|c|c|c|c|c|c|c|c|c|}
\hline & \multicolumn{8}{|c|}{ Algorithm } \\
\hline & & GLM & GBM & RF & СТА & MARS & ANN & FDA & MAXENT \\
\hline \multirow[t]{3}{*}{$R O C$} & mean & 0.844 & 0.845 & 0.866 & 0.806 & 0.848 & 0.849 & 0.844 & 0.838 \\
\hline & sd & 0.008 & 0.009 & 0.010 & 0.013 & 0.009 & 0.010 & 0.009 & 0.009 \\
\hline & MaxSS & 413.1 & 525.3 & 204.6 & 521.8 & 398.1 & 457.2 & 376.8 & 359.0 \\
\hline \multirow[t]{3}{*}{ TSS } & mean & 0.561 & 0.552 & 0.586 & 0.536 & 0.567 & 0.575 & 0.555 & 0.547 \\
\hline & sd & 0.016 & 0.023 & 0.017 & 0.018 & 0.021 & 0.018 & 0.018 & 0.022 \\
\hline & MaxSS & 412.9 & 522.0 & 203.0 & 517.1 & 402.6 & 442.6 & 371.3 & 359.0 \\
\hline \multicolumn{10}{|c|}{ Ensemble evaluation scores } \\
\hline & $\mathrm{ROC}$ & 0.799 & 0.817 & 0.959 & 0.857 & 0.819 & 0.856 & 0.810 & 0.811 \\
\hline & MaxSS & 850.0 & 277.5 & 550.0 & 277.5 & 550.0 & 550.0 & 450.0 & 611.5 \\
\hline \multicolumn{10}{|c|}{ Variable Importance (normalized) } \\
\hline & $\operatorname{pmax}$ & -1.288 & -0.483 & -1.390 & -0.624 & -1.141 & -0.874 & -0.984 & -0.851 \\
\hline & pmin & 1.236 & 1.005 & 0.818 & 0.915 & 1.176 & 0.918 & 1.250 & 1.444 \\
\hline & psum & -0.230 & -1.068 & -1.192 & -1.145 & -0.267 & -0.840 & -0.064 & -0.827 \\
\hline & $\operatorname{tmax}$ & -0.301 & -0.798 & -0.201 & -1.086 & -0.308 & -0.017 & -0.267 & -0.677 \\
\hline & tmean & 1.409 & -0.347 & 1.047 & 1.419 & 1.496 & 1.702 & 1.335 & -0.448 \\
\hline & $\operatorname{tmin}$ & -0.826 & 1.691 & 0.918 & 0.521 & -0.955 & -0.889 & -1.269 & $\begin{array}{l}1.359 \\
\end{array}$ \\
\hline
\end{tabular}

Shown are also the threshold values under Maximum Sensitivity and Specificity (MaxSS) as well as the normalized variable importance for each predictor and algorithm. For better visualization and comparability, importance values are highlighted by bars $($ blue $=$ positive, red $=$ negative, size $=$ strength). 
strongholds of the species on the Iberian Peninsula, in Italy and Romania show high suitability values (Fig. 3). This pattern is obvious for all model algorithms, although there are some differences in suitability for Central and Northern Europe, mainly for the MAXENT and GBM algorithms, which mostly show unsuitable conditions north of the Alps (Fig. 3). In addition, outside of our focus area, large parts of the realized distribution in Asia and easternmost Europe were not recognized as suitable.

Focussing on Germany, all models were able to predict suitable areas along the upper Rhine valley. However, the breeding population in Eastern Germany was not predicted by all models (Fig. S1). Furthermore, patterns of overprediction are obvious in Northern Europe, often in coastal areas around the Baltic Sea and the North Sea.

\section{Climate suitability and population size}

Linear regression models showed significant positive relationships between the climatic suitable area and population size across European countries (Table 2). The average coefficient of determination was considerable $\left(R^{2}=0.411\right)$ and ranged between $R^{2}=0.287$ in MARS and $R^{2}=0.653$ in GBM (Table 2). For most algorithms, the German population size of the European Bee-eater falls within confidence limits of this relationship with climatic suitability (Table 2; Fig. 2). Only two algorithms, ANN and RF, overpredicted the amount of suitable area in Germany, and GBM slightly underpredicted the area (Table 2). A few other countries show strong deviations from these relationships, namely: Belarus (for CTA, FDA, GBM, GLM, MARS, MAXENT), Latvia (for CTA, GBM, MAXENT, RF), and Lithuania (for CTA, GBM and MAXENT), where the respective algorithms failed to predict suitable distribution and hence underestimated population sizes in that country (Fig. 4).
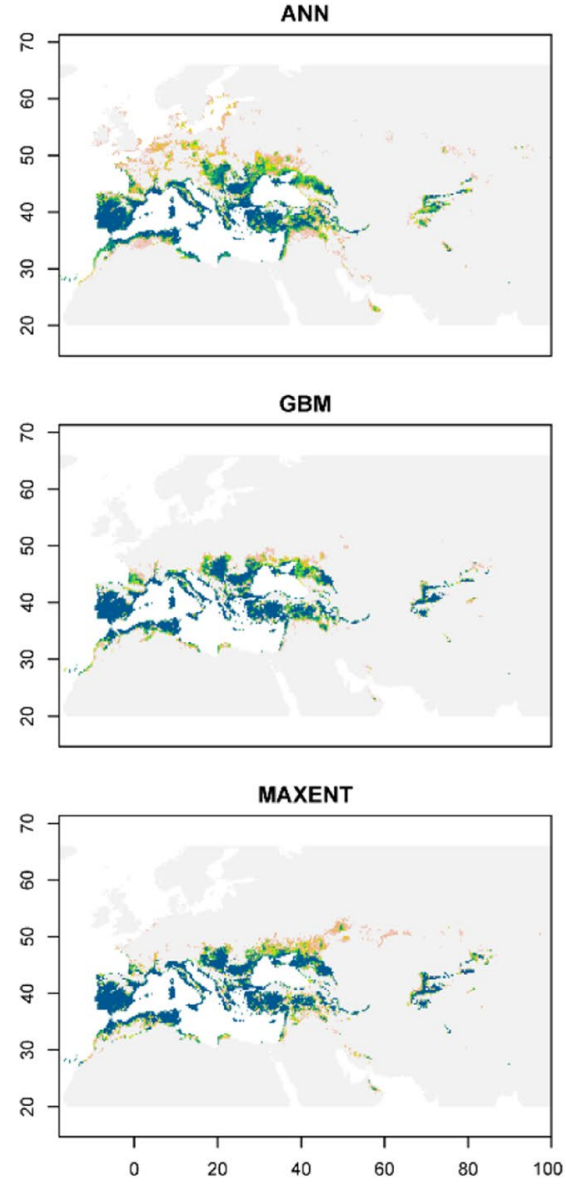

CTA

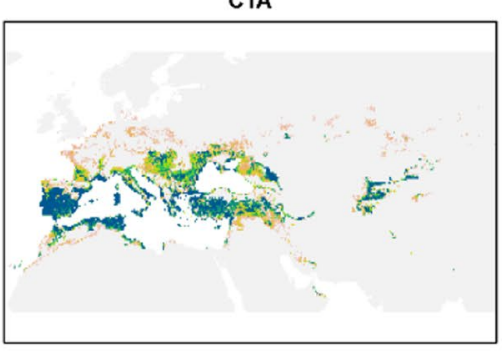

GLM

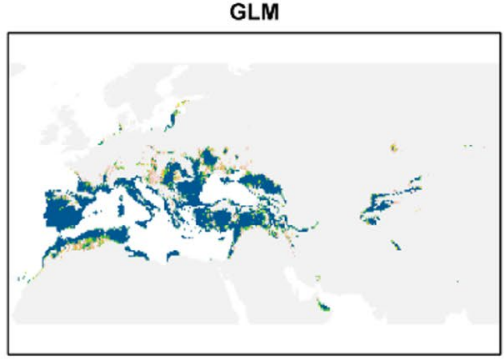

RF

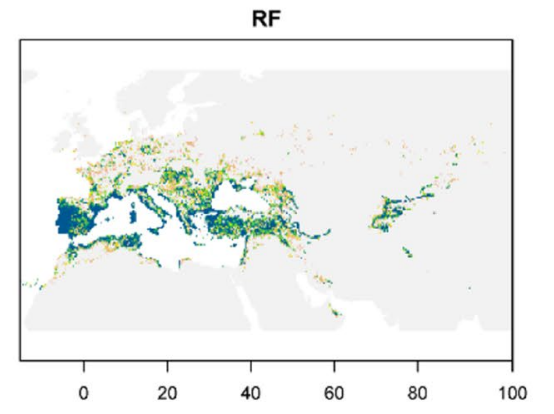

Number of models in ensemble
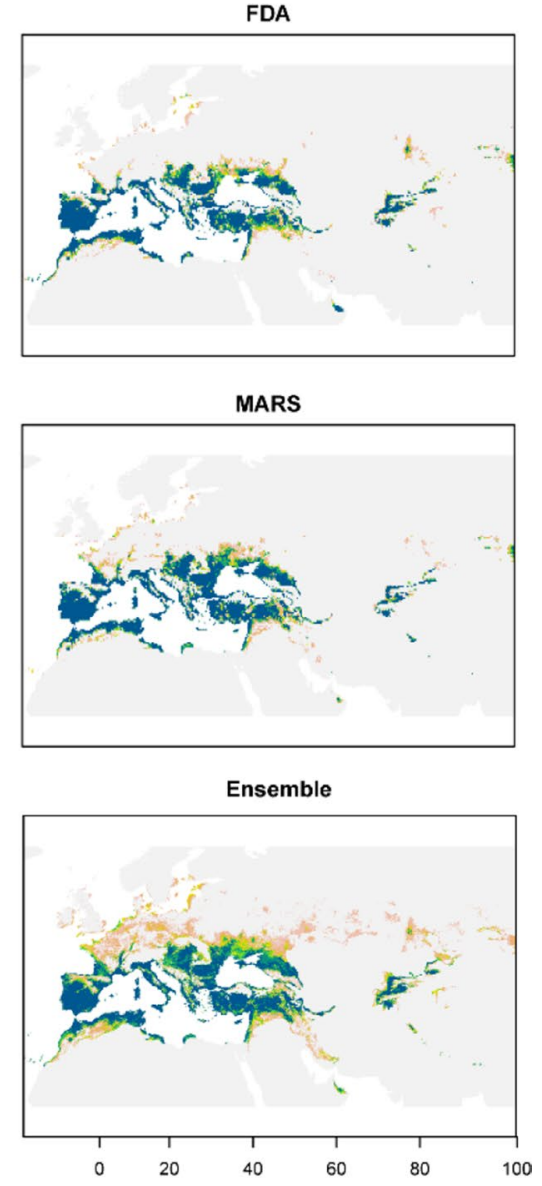

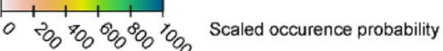

Fig. 3 Predicted occurrence probability for each of eight model algorithms and stacked map of the entire ensemble 
Table 2 Relationship between suitable area (i.e. number of cells $>$ threshold value cutoff) and population size estimates for 20 European countries with known breeding records of European Bee-eaters

\begin{tabular}{llrlrrr}
\hline Algorithm & $R^{2}$ & \multicolumn{7}{l}{ Germany } \\
\cline { 3 - 7 } & & & $\begin{array}{l}\text { Suitable area } \\
\text { (\#cells) }\end{array}$ & Suitable area fitted & $95 \%$ CI & \\
\hline ANN & 0.392 & 0.002 & $\mathbf{2 1 5 , 7 2 6}$ & 67,383 & 34,321 & 132,291 \\
CTA & 0.350 & 0.004 & 117,428 & 25,096 & 4,630 & 136,023 \\
FDA & 0.399 & 0.002 & 18,462 & 25,060 & 7,755 & 80,974 \\
GBM & 0.653 & $<0.001$ & 1,222 & 7,442 & 1,788 & 30,965 \\
GLM & 0.333 & 0.005 & 24,232 & 34,072 & 9,910 & 117,140 \\
MARS & 0.287 & 0.009 & 50,331 & 35,844 & 10,876 & 118,125 \\
MAXENT & 0.467 & 0.001 & 4,370 & 13,223 & 2,974 & 58,783 \\
RF & 0.406 & 0.002 & $\mathbf{1 8 8 , 5 9 2}$ & 43,742 & 14,463 & 132,289 \\
\hline
\end{tabular}

Estimates of suitable areas are based on model ensembles for each of nine algorithms. In addition, values from Germany are shown to check whether the estimates deviate (i.e. outside of $95 \%$ confidence limits) strongly from the model fit

Bold estimates highlight overpredicted, italicized estimates highlight underpredicted area sizes

\section{Future potential distribution}

The RCP4.5 models predict a northward shift of the distribution of the European Bee-eater for both circulation models (Fig. 5a, b). Differences between MIROC and CCSM are small, with MIROC pointing to high suitability areas in Central and Eastern Europe for nearly all model algorithms. As with the current distribution, model algorithms also differ slightly in potential future distribution (Fig. S2). Following the RCP8.5 scenario, areas in the south of the current distribution remain largely suitable, while many areas in Central and Northern Europe become less suitable than under the RCP4.5 scenario (Fig. 5c, d). Notably, differences between GCMs are much more pronounced and variation among algorithms is high, particularly under the MIROC GCM (Fig. S3). As under the MIROC RCP8.5 scenario, the GLM model even shows a nearly complete loss of suitable area, we largely discard these results from the discussion.

\section{Discussion}

The recent range expansion of the European Bee-eater in Central Europe is often associated with changing climate. In this study, we performed SDMs to test this relationship. Our results confirm a close relationship between climate and realized distribution of the species particularly for the German population. Future predictions point to range extensions at higher latitudes while results also depend on selected model conditions.

\section{Comparison of model approaches}

We used eight modelling algorithms to predict the potential current and future distribution of European Bee-eaters.
While we do not recommend to infer generalizations from the results of our single species study in a limited geographical area, our comparison of different model algorithms seems appropriate. Differences in statistical parameters, such as the often criticized AUC values (Lobo et al. 2008; Jiménez-Valverde 2012), were mostly small and output maps had many similarities. Hence, at first glance, an ensemble approach might have been unnecessary. However, we underline the robustness of our results by testing various approaches as has been shown in previous studies (Qiao et al. 2015; Scales et al. 2016). Moreover, a few output maps stand clearly out, in particular, GBM and Maxent, which hardly predict higher latitude populations under current climate. One possible explanation for their deviation in our study might be their different assessment of variable contributions. While mean temperature was the highest contributing thermal variable in all other algorithms, GBM and MAXENT assigned high importance exclusively to minimum temperature (Table 1). Favouring extreme values over averages may thus lead to more restrictive model outputs: in our case, the predicted unsuitability within the realized distribution of the European Bee-eater in higher latitudes such as Central Europe or the Baltic states. Model outputs vary more distinctly for future predictions, as has been shown elsewhere (Pearson et al. 2006; Ashraf et al. 2017). For instance, the MIROCGLM-RCP8.5 model predicts a nearly complete loss of suitable areas over the whole breeding range. Again this calls for caution if relying on single model approaches, but offers the opportunity to identify algorithms, GCMs and RCPs that perform less well (Quillfeldt et al. 2017; Thuiller et al. 2019). Each model depends on many factors and our results do not allow to single out a best model approach (Marmion et al. 2009). By performing an ensemble approach, we account for the variation in 

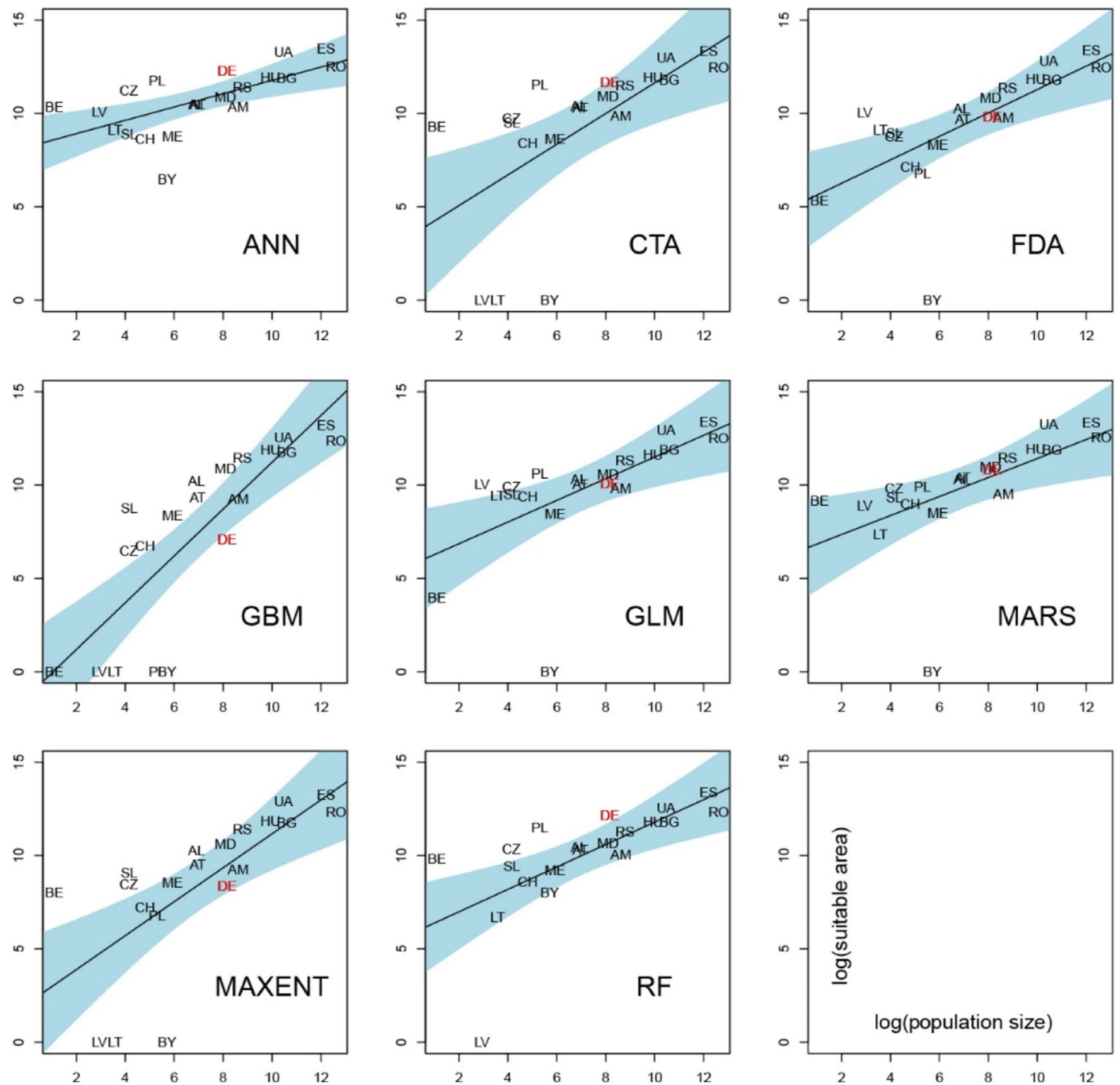

Fig. 4 Relationship between the area predicted suitable and the population size for a total of 20 European breeding countries and eight algorithms. Country names are given as ISO3166 alpha- 2 codes with
Germany being highlighted in red. Shaded areas around the regression line highlight $95 \%$ confidence limits. Both axes are $\log (x+1)$ scaled

\section{Current potential distribution} odology (Araújo and New 2007; Elith and Graham 2009; Jones-Farrand et al. 2011; Quillfeldt et al. 2017). A stack of different model outputs has been used for modelling the distribution of a plethora of bird species (e.g. Coetzee et al. 2009; Barbet-Massin et al. 2010; Strubbe et al. 2015; Scales et al. 2016), and we confirm the usefulness of this best practice approach, but also point to model-specific features.
The modelled and the realized distribution of the European Bee-eater in the Western Palaearctic are highly similar. Parts of eastern and northern Germany, which were not predicted by all models, have only been colonized by larger numbers of European Bee-eaters within the time frame considered in this study. Hence, the climate data used here could have been inappropriate to describe these fast range dynamics under 

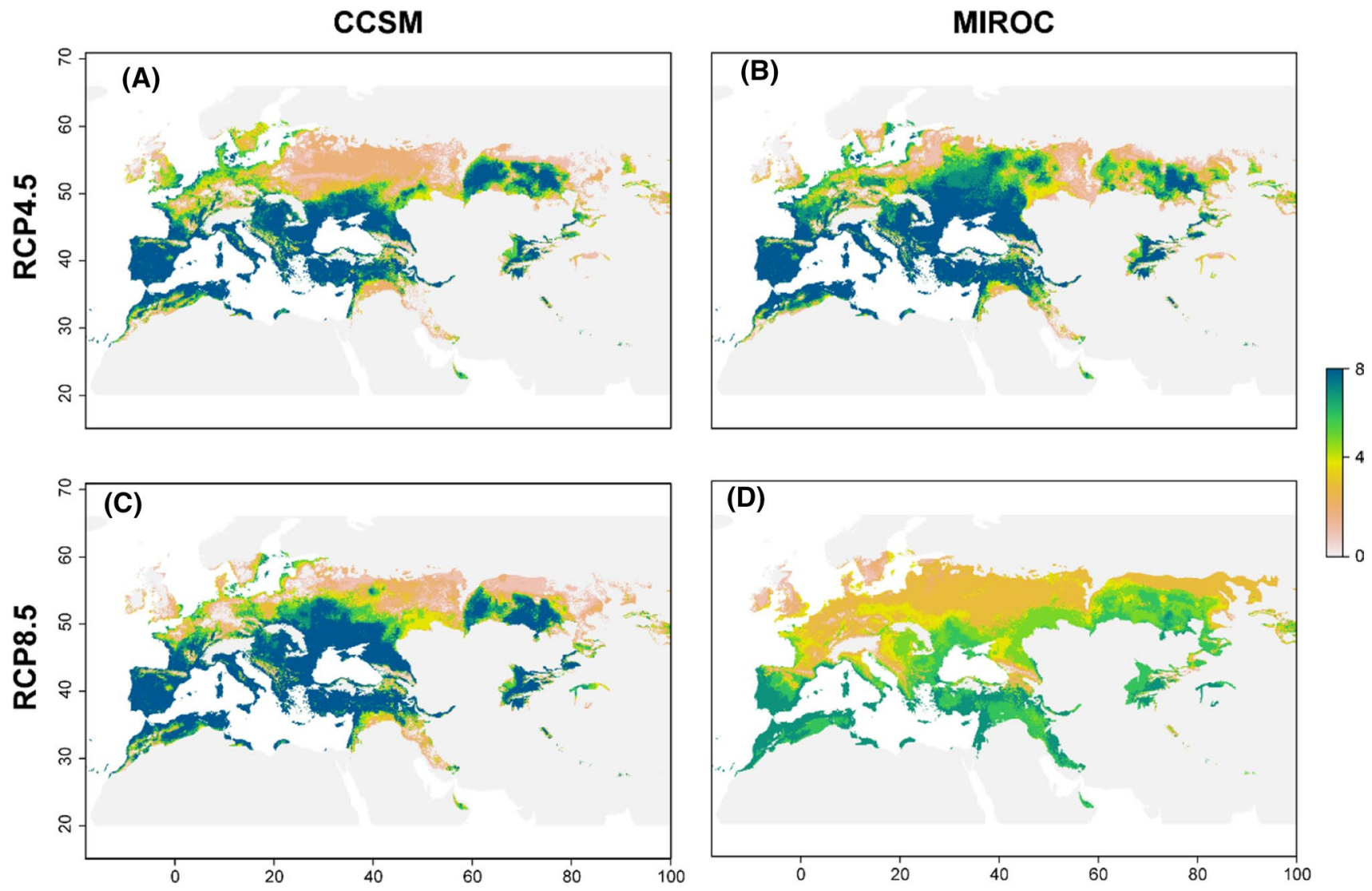

Fig. 5 Ensemble forecasts for the year 2050 using two global circulation models (CCSM and MIROC) and two relative concentration pathways (RCP 4.5 and 8.5). Shading represents the number of algorithms predicting potential occurrence within the background area

rapid global warming. In Central Europe, breeding performance of European Bee-eaters strongly depends on weather conditions (Arbeiter et al. 2016) offering a role for shortterm effects that could conceal effects of climate (Reside et al. 2010). Alternatively, some model approaches, notably Maxent and GBM, underestimated the potential climate niche of the study species. These models partially result in patterns similar to the early assumptions by Voous (1960) who set the northern range edge at the $21^{\circ} \mathrm{C}$ July isothermal line with some breeding records below these values. Yet, most algorithms revealed some areas of niche unfilling, i.e. geographic areas that are climatically suitable but uninhabited by the species. These areas are often concentrated along the coasts of Western Europe and the Baltic Sea. Interestingly, there are breeding records from some of these regions (e.g. Birdlife International 2015), but large and persistent colonies are still to be established by the species. While dispersal limitation is often regarded as one range delimiting factor in organisms (Soberón and Peterson 2005), the high mobility of a long-distance migratory bird species known for being a vagrant across many non-breeding areas, (e.g. www. tarsiger.com, last access 20.01.2020) renders explanation based on dispersal unlikely. However, poleward range shifts in such long-distance migrants are associated with greater migration distances that could also limit further northward range extensions (Doswald et al. 2009; Fiedler et al. 2016; Zurell et al. 2018; Curley et al. 2019). While we acknowledge the great importance of considering the full annual cycle of a migratory species (e.g. Barbet-Massin et al. 2009; Williams et al. 2017; Zurell et al. 2018), data on the wintering behaviour of our study species are far less available than on the breeding distribution, making their consideration a task for future studies. Alternatively, habitat characteristics and reduced food availability, e.g. due to a severe decline of flying insects (Hallmann et al. 2017), could explain some areas of niche unfilling. However, range expansions are a dynamic process that typically occurs uneven over large spatial scales (Veech et al. 2011). Moreover, density-dependent reproductive success known as Allee effects might influence the expansion of a colonial breeding bird species (Serrano et al 2005) but are beyond the scope of our study. Finally, as for all range shifting species, the range expansion of the European Bee-eater conflicts the equilibrium assumptions of SDMs (see Elith et al. 2010 for an overview). SDMs assume that the distribution of a species is in balance with the climatic conditions shaping it. When a species' range shifts, 
either favourable climatic conditions stretch far beyond what a species was able to colonize yet (i.e. creating a time lag in species response to climate change) or a species expands into novel climatic combinations not reflected in the original range but which are still favourable (e.g. as for many invasive species). This disequilibrium in the species-environment relationship in the European Bee-eater may explain underestimated regions of the realized distribution but also the strong variation in future predictions (see below, Elith et al. 2010). In sum, no matter whether the source of uncertainty in the predictions arises for methodological or biological reasons, overall model outputs still underline climate as main driver of the European and German current distribution of the European Bee-eater.

\section{Relationship between climate suitability and population size}

The positive relationship between climate suitability and population size among European countries is in concordance with our hypotheses that the breeding distribution of the European Bee-eater is mainly defined by climatic factors. This includes the German population which fits within or is close to the $95 \%$ confidence interval. Besides this general relationship, however, we found that confidence limits stretch widely - often by two orders of magnitude in most model approaches. This is most likely due to a combination of uncertainties in the predicted suitable areas from the respective SDM but also in the country-level population estimates. It is noteworthy that some model approaches predicted population size appropriately, but were not able to reveal the underlying spatial pattern. For instance, FDA, GBM, GLM, and Maxent failed to predict the large populations in eastern Germany and potentially overestimated population sizes in southwestern Germany. ANN and RF show patterns of overprediction as many areas defined as suitable contrast to the realized distribution of European Bee-eaters in Germany. From this, while the amount of suitable area in Germany is in line with the population estimate, the location of suitable areas often diverges from the realized distribution of European bee-eaters in Germany calling for a closer inspection of the colonization history in the country and using climate information of finer temporal resolution.

On a European scale, the positive correlation between population size and climate suitability for Belarus and the Baltic states of Latvia and Lithuania was absent for some SDMs. This is possibly due to a lower data coverage in Eastern Europe and Asia compared to Western and Southern Europe (Fourcade et al. 2014b). Belarus was in almost any algorithm far outside the confidence limits (Fig. 4) and excluding this single country alone from the country-level analysis of the amount of suitable area from population size improved that relationship tremendously (data not shown).
Besides methodological effects of data coverage and quality, spatial variation of predictor variable collinearity could be a further reason that would call for further investigation. However, we confirm the general positive relationship of environmental factors and abundance (VanDerWal et al. 2009; Thuiller 2014) and add to the studies that infer data on avian population size and density from SDMs (Oliver et al. 2012; Barker et al. 2014; Carrascal et al. 2015).

Recent declines in southern parts of the range as observed e.g. in Turkey (Birdlife International 2015) occur in areas that show suitable conditions under current and most future projections. Hence, we hesitate to link these patterns to direct effects of global warming. Instead, other factors like agricultural intensification and bird hunting should not be neglected as possible explanations (Donald et al. 2001; Brochet et al. 2016). Moreover, European Bee-eaters need large flying insects as food which have shown marked declines in recent years and are particularly affected by climate change (Hallmann et al. 2017; Soroye et al. 2020) offering the potential for indirect negative effects on populations of European Bee-eaters.

\section{Future potential distribution}

Future projections under the RCP4.5 emission scenario predict a shift of the northern range edge as has already been shown for many species (e.g. Thomas and Lennon 1999). Areas in Sweden, where the species already bred in the past (Cramp 1985), and southern Finland will have suitable climate, while predictions for large parts of the United Kingdom, where the species already bred (e.g. Holling and Rare Breeding Birds Panel 2017), vary depending on selected algorithms. Future projections under the RCP8.5 emission scenario showed a large variation in suitable climate according to the two GCMs considered. However, while the CCSM RCP8.5 showed a level of consistency among SDM algorithms compared to the RCP4.5 GCMs, the MIROC RCP8.5 predictions deviated strongly from each other-up to a point where the entire current distribution was predicted unsuitable (in the GLM, Fig. S3). One possible explanation is that climatic changes diverge strongest among GCMs in RCP8.5 as this represents the worst-case scenario in future global climate developments (Hausfather and Peters 2020). Under these extreme conditions, some GCMs could predict locally much stronger changes than others-with profound effect of SDM projections. Differences between circulation models have also been shown for other projections, stressing the need for considering more than one GCM (Schidelko et al. 2011, 2013; Thuiller et al. 2019). However, further research is needed to compare how strong and in which geographic areas and under which RCP GCMs are diverging most. In contrast to other bird species, losses of suitable breeding range of the European Bee-Eater were not concentrated on 
the southern range edge (Thomas and Lennon 1999; Virkkala and Lehikoinen 2014), and these areas remain climatically suitable under most predictions. Based on climate projections, our study species could well survive in the Maghreb area, which has been previously shown to be important for future avian diversity under climate change (Barbet-Massin et al. 2010). Hence, our hypothesis that global warming will heavily affect the species in the southernmost parts of its range is not supported by our results. European Bee-eaters might be tolerant to predicted rising temperatures, perhaps due to plasticity in thermoregulatory behaviour (Glutz von Blotzheim 1980; Yosef 2010). While the species even breeds in desert areas, it is typically confined to river valleys and other specific habitats, which were not considered within our approach.

\section{Conclusions}

Taken together, the European Bee-eater might indeed be an iconic messenger of climate change. At least in the short-term and under medium emission scenarios, European Bee-eaters are predicted to shift northwards, while currently populated areas remain suitable, especially in the south of the distribution. More regionally, the current population size in Germany can be predicted by climatic conditions during the breeding season by most algorithms and is in line with conditions in other European countries. Therefore, the European Bee-eater can be regarded as an appropriate 'indicator species' for global warming in Central Europe (see Gregory et al. 2009), and we emphasize the need for species-specific analyses of European species' distributions under climate change. Future studies on regional short-term population dynamics of the European Bee-eater should consider weather (Arbeiter et al. 2016) and the availability of suitable breeding habitats.

Supplementary Information The online version contains supplementary material available at https://doi.org/10.1007/s10336-021-01867-z.

Acknowledgements We would like to thank everybody who contributed bee-eater sightings to public repositories without which our research would not be possible. We further thank the German Ornithologists' Society for supporting our work with a data analysis grant. J.O.E. received a Postdoctoral Fellowship from the Research Foundation-Flanders (FWO; 12G4317N).

Author contributions All authors contributed to the ideas of the project. Analysis was led by JOE with critical input from DS. DS led the writing with support from JOE and KS. All authors contributed to the drafts and gave final approval for publications. The authors declare no conflict of interest.

Funding Open Access funding enabled and organized by Projekt DEAL.
Open Access This article is licensed under a Creative Commons Attribution 4.0 International License, which permits use, sharing, adaptation, distribution and reproduction in any medium or format, as long as you give appropriate credit to the original author(s) and the source, provide a link to the Creative Commons licence, and indicate if changes were made. The images or other third party material in this article are included in the article's Creative Commons licence, unless indicated otherwise in a credit line to the material. If material is not included in the article's Creative Commons licence and your intended use is not permitted by statutory regulation or exceeds the permitted use, you will need to obtain permission directly from the copyright holder. To view a copy of this licence, visit http://creativecommons.org/licenses/by/4.0/.

\section{References}

Allouche O, Tsoar A, Kadmon R (2006) Assessing the accuracy of species distribution models: prevalence, kappa and the true skill statistic (TSS). J Appl Ecol 43:1223-1232

Araújo MB, New M (2007) Ensemble forecasting of species distributions. Trends Ecol Evol 22:42-47

Araújo MB, Pearson RG, Thuiller W, Erhard M (2005) Validation of species-climate impact models under climate change. Glob Change Biol 11:1504-1513

Arbeiter S, Schulze M, Tamm P, Hahn S (2016) Strong cascading effect of weather conditions on prey availability and annual breeding performance in European bee-eaters Merops apiaster. J Orn 157:155-163

Ashraf U, Peterson AT, Chaudhry MN, Ashraf I, Saqib Z, Ahmad SR, Ali H (2017) Ecological niche model comparison under different climate scenarios: a case study of Olea spp. Asia Ecosphere 8(5):e01825. https://doi.org/10.1002/ecs2.1825

Barbet-Massin M, Walther BA, Thuiller W, Rahbek C, Jiguet F (2009) Potential impacts of climate change on the winter distribution of Afro-Palearctic migrant passerines. Biol Let 5:248-251

Barbet-Massin M, Thuiller W, Jiguet F (2010) How much do we overestimate future local extinction rates when restricting the range of occurrence data in climate suitability models? Ecography 33:878-886

Barker NKS, Cumming SH, Darveau M (2014) Models to predict the distribution and abundance of breeding ducks in Canada. Avian Conserv Ecol 9(2):7. https://doi.org/10.5751/ACE-00699-090207

Bauer H-G, Bezzel E, Fiedler W (eds) (2005) Das Kompendium der Vögel Mitteleuropas. Nonpasseriformes - Nichtsperlingsvögel, Aula-Verlag

BirdLife International (2015) European Red List of birds. Office for Official Publications of the European Communities, Luxembourg

Brochet AL, van den Bossche W, Jbour S, Ndanganga PK, Jones VR, Abdou WALI, Al-Hmoud AR, Asswad NG, Atienza JC, Atrash I, Barbara N, Bensusan K, Bino T, Celada C, Cherkaoui SI, Costa J, Deceuninck B, Etayeb KS, Feltrup-Azafzaf C, Figelj J, Gustin M, Kmecl P, Kocevski V, Korbeti M, Kotrošan D, Laguna MJ, Lattuada M, Leitão D, Lopes P, López-Jiménez N, Lucić V, Micol T, Moali A, Perlman Y, Piludu N, Portolou D, Putilin K, Quaintenne G, Ramadan-Jaradi G, Ružić M, Sandor A, Sarjli N, Saveljić D, Sheldon RD, Shialis T, Tsiopelas N, Vargas F, Thompson C, Brunner A, Grimmet R, Butchart SM (2016) Preliminary assessment of the scope and scale of illegal killing and taking of birds in the Mediterranean. Bird Conserv Int 26:1-28

Carrascal LM, Aragón P, Palomino D, Lobo JM (2015) Predicting regional densities from bird occurrence data validation and effects of species traits in a Macaronesian island. Divers Distrib 21:1284-1294 
Chen I-C, Hill JK, Ohlemüller R, Roy DB, Thomas CD (2011) Rapid range shifts of species associates with high levels of climate warming. Science 333:1024-1026

Coetzee BWT, Robertson MP, Erasmus BFN, van Rensburg BJ, Thuiller W (2009) Ensemble models predict Important Bird Areas in southern Africa will become less effective for conserving endemic birds under climate change. Global Ecol Biogeogr 18:701-710

Cramp S (ed) (1985) Handbook of the birds of Europe the Middle East and North Africa. Oxford University Press, Oxford

Curley SR, Manne LL, Veith RR (2019) Differential winter and breeding range shifts: Implications for avian migration distances. Divers Distr. https://doi.org/10.1111/ddi.13036

Devictor V, Julliard R, Couvet D, Jiguet F (2008) Birds are tracking climate warming, but not fast enough. Proc R Soc B Biol Sci 275:2743-2748

Donald PF, Green RE, Heath MF (2001) Agricultural intensification and the collapse of Europe's farmland bird populations. Proc R Soc Lond B 268:25-29

Doswald N, Willis SG, Collingham YC, Pain DJ, Green RE, Huntley B (2009) Potential impacts of climate change on the breeding and non-breeding ranges and migration distance of European Sylvia warblers. J Biogeogr 36:1194-1208

Elith J, Graham CH (2009) Do they? How do they? WHY do they differ? On finding reasons for differing performances of species distribution models. Ecography 32:66-77

Elith J, Leathwick JR (2009) Species distribution models: ecological explanation and prediction across space and time. Annu Rev Ecol Evol Syst 40:677-697

Elith J, Graham CH, Anderson RP, Dudik M, Ferrier S, Guisan A, Hijmans RJ, Huettmann F, Leathwick JR, Li J, Lohmann LG, Loiselle BA, Manion G, Moritz C, Nakamura M, Nakazawa Y, Overton JMM, Peterson AT, Phillips SJ, Richardson K, Scachetti-Pereira R, Schapire RE, Soberón J, Williams S, Wisz MS, Zimmermann NE (2006) Novel methods improve prediction of species' distributions form occurrence data. Ecography 29:129-151

Elith J, Kearney M, Phillips S (2010) The art of modelling rangeshifting species. Methods Ecol Evol 1:330-342

Engler JO, Rödder D, Elle O, Hochkirch A, Secondi J (2013) Species distribution models contribute to determine the effect of climate and interspecific interactions in moving hybrid zones. J Evol Biol. https://doi.org/10.1111/jeb.12244

Engler JO, Stiels D, Schidelko K, Strubbe D, Quillfeldt P, Brambilla M (2017) Avian SDMs: current state, challenges, and opportunities. J Avian Biol 48:1483-1504

Essel S, Bastian A, Valentin H-V, Weiss J, Tietze DT (2016) Ausbreitung des Bienenfresser (Merops apiaster) in Rheinland-Pfalz von 1992-2015. Fauna Flora Rheinland-Pfalz 13:331-350

Fiedler W (2016) Chapter 8 - Bird ecology. In: Letcher TM: Climate change - Observed impacts on earth. Elsevier, Amsterdam, Boston, Heidelberg, London, New York, Oxford, Paris, San Diego, San Francisco, Singapore, Sydney, Tokyo

Fielding AH, Bell JF (1997) A review of methods for the assessment of prediction errors in conservation presence/absence models. Environ Conserv 24:38-49

Fourcade Y, Engler JO, Rödder D, Secondi J (2014a) Mapping species distributions with MAXENT using a geographically biased sample of presence data: a performance assessment of methods for correcting sampling bias. PLoS ONE 9(5):e97122. https://doi. org/10.1371/journal.pone.0097122

Fourcade Y, Engler JO, Besnard AG, Rödder D, Secondi J (2014b) Confronting expert-based and modelled distributions for species with uncertain conservation status: a case study from the corncrake (Crex crex). Biol Conserv 167:161-171

Freeman BG, Lee-Yaw JA, Sunday JM, Hargreaves AL (2018) Expanding, shifting and shrinking: the impact of global warming on species' elevational distributions. Global Ecol Biogeogr. https:// doi.org/10.1111/geb.12774

Fry CH (1988) Meropidae, bee-eaters. In: Fry CH, Keith S, Urban EK (eds) The birds of Africa. Vol 3. Academic Press, London, San Diego, New York, Boston, Sydney, Tokyo

Fry CH (2001) Family Meropidae (Bee-eaters). pp 286-341. In: del Hoyo J, Elliott A, Sargatal A (eds) Handbook of the birds of the world. Vol 6. Mousebirds to Hornbills. Lynx Edicions, Barcelona

Fry H \& Boesman P 2020. European Bee-eater (Merops apiaster). In: del Hoyo, J., Elliott, A., Sargatal, J., Christie, D.A. \& de Juana, E. (eds.). Handbook of the Birds of the World Alive. Lynx Edicions, Barcelona. https://www.hbw.com/node/55850 Acceseed 2 March 2020

Gedeon K, Grüneberg C, Mitschke A, Sudfeldt C, Eikhorst W, Fischer S, Flade M, Frick S, Geiersberger I, Koop B, Kramer M, Krüger T, Roth N, Ryslavy T, Stübing S, Sudmann SR, Steffens R, Vökler F, Witt K (2014) Atlas Deutscher Brutvogelarten. Atlas of German Breeding Birds. Stiftung Vogelmonitoring Deutschland und Dachverband Deutscher Avifaunisten, Münster

Gerber A, Leuthold W, Kéry M (2011) Der Bienenfresser Merops apiaster in der Schweiz: Durchzug und Bruten. Der Ornithologische Beobachter 108:101-116

Glutz von Blotzheim UN, Bauer KM (1980) Handbuch der Vögel Mitteleuropas Band Columbiformes Piciformes. Akademische Verlagsgesellschaft, Wiesbaden

Gregory RD, Willis SG, Jiguet F, Voříšek P, Klvaňvá A, van Strien A, Huntley B, Collingham YC, Couvet D, Green RE (2009) An indicator of the impact of climatic change on European bird populations. PLoS ONE 4(3):e4678. https://doi.org/10.1371/journal. pone. 0004678

Guisan A, Thuiller W (2005) Predicting species distribution: offering more than simple habitat models. Ecol Lett 8:993-1009

Guisan A, Petitpierre B, Broennimann O, Daehler C, Kueffer C (2014) Unifying niche shift studies: insights from biological invasions. Trends Ecol Evol 29:260-269

Hallmann CA, Sorg M, Jongejans E, Siepel H, Hofland N, Schwan H, Stenmans W, Müller A, Sumser H, Hörren T, Goulson D, de Kroon H (2017) More than 75 percent decline over 27 years in total flying insect biomass in protected areas. PLoS ONE 12(10):e0185809. https://doi.org/10.1371/journal.pone.0185809

Hausfather Z, Peters GP (2020) Emissions - the 'business as usual' story is misleading. Nature 577:618-620

Heneberg P, Šimeček K (2004) Nesting of European Bee-eaters (Merops apiaster) in Central Europe depends on soil characteristics of nest sites. Biologia Bratislava 59:205-211

Herrando S, Keller V, Bauer HG, Brotons L, Eaton M, Kalyakin M, Voltzit O, Lehikoinen A, Milanesi P, Noble D, Ramírez I, Voříšek P, Foppen R (2019) Using the first European Breeding Bird Atlas for science and perspectives for the new Atlas. Bird Study 66:149-158

Hickling R, Roy DB, Hill JK, Fox R, Thomas CD (2006) The distributions of a wide range of taxonomic groups are expanding polewards. Glob Change Biol 12:450-455

Hijmans RJ, Cameron SE, Parra JL, Jones PG, Jarvis A (2005) Very high resolution interpolated climate surfaces for global land areas. Int J Climatol 25:1965-1978

Hijmans RJ, Phillips S, Leathwick J, Elith J (2016) dismo: Species Distribution Modeling. R package version 1.1-1. https://CRAN.Rproject.org/package $=$ dismo

Holling M, Rare Breeding Birds Panel (2017) Rare breeding birds in the UK 2015. British Birds 110:706-754

IPCC (2014) Climate Change 2014: Synthesis Report. Contribution of Working Groups I, II and III to the Fifth Assessment Report of the Intergovernmental Panel on Climate Change [Core Writing Team, R.K. Pachauri and L.A. Meyer (eds)]. IPCC, Geneva 
Jiguet F, Gregory RD, Devictor V, Green RE, Voříšek P, van Strien A, Couvet D (2010) Population trends of European common birds are predicted by characteristics of their climatic niche. Glob Change Biol 16:497-505

Jiménez-Valverde A (2012) Insights into the area under the receiver operating characteristic curve (AUC) as a discrimination measure in species distribution modelling. Global Ecol Biogeogr 21:498-507

Jones-Farrand DT, Fearer TM, Thogmartin WE, Thompson FR III, Nelson MD, Tirpak JM (2011) Comparison of statistical and theoretical habitat models for conservation planning: the benefit of ensemble prediction. Ecol Appl 21:2269-2282

Karger DN, Conrad O, Böhner J, Kawohl T, Kreft H, Soria-Auza RW, Zimmermann NE, Linder HP, Kessler M (2017a) Climatologies at high resolution for the earth's land surface areas. Scientific Data 4:170122

Karger DN, Conrad O, Böhner J, Kawohl T, Kreft H, Soria-Auza RW, Zimmermann NE, Linder HP, Kessler M (2017b) Data from: climatologies at high resolution for the earth's land surface areas. Dryad Digital Repos. https://doi.org/10.5061/dryad.kd1d4

Kinzelbach R, Nicolai B, Schlenker R (1997) Der Bienenfresser Merops apiaster als Klimazeiger: Zum Einflug in Bayern, der Schweiz und Baden im Jahr 1644. J Orn 138:297-306

Krištín A, Kaňuch P (2005) Is Bee-eater (Merops apiaster) spreading northwards? To occurrence and diet in the Podpolanie and Zvolen area (central Slovakia). Tichodroma 17:89-94

La Sorte FA, Jetz W (2012) Tracking of climatic niche boundaries under recent climate change. J Anim Ecol 81:914-925

Ławicki L (2014) The Great White Egret in Europe: population increase and range expansion since 1980. Br Birds 107:8-25

Lobo JM, Jiménez-Valverde A, Real R (2008) AUC: a misleading measure of the performance of predictive distribution models. Glob Ecol Biogeogr 17:145-151

Marmion M, Luoto M, Heikkinen RK, Thuiller W (2009) The performance of state-of-the-art modelling techniques depends on geographical distribution of species. Ecol Model 220:3512-3520

Monahan WB, Tingley MW (2012) Niche tracking and rapid establishment of distributional equilibrium in the House Sparrow show potential responsiveness of species to climate change. PLoS ONE 7(7):e42097. https://doi.org/10.1371/journal.pone.0042097

Oliver TH, Gillings S, Girardello M, Rapacciuolo G, Brereton TM, Siriwardena GM, Roy DB, Pywell R, Fuller RJ (2012) Population density but not stability can be predicted from species distribution models. J Appl Ecol 49:581-590

Olson DM, Dinerstein E, Wikramanayake ED, Burgess ND, Powell GVN, Underwood EC, D'Amico JA, Itoua I, Strand HE, Morrison JC, Loucks CJ, Allnutt TF, Ricketts TH, Kura Y, Lamoreux JF, Wettengel WW, Hedao P, Kassem KR (2001) Terrestrial ecoregions of the world: a new map of life on earth. Bioscience 51:933-938

Parmesan C, Yohe G (2003) A globally coherent fingerprint of climate change impacts across natural systems. Nature 421:37-42

Pearson RG, Dawson TE (2003) Predicting the impacts of climate change on the distribution of species: are bioclimate envelope models useful? Glob Ecol Biogeogr 12:361-371

Pearson RG, Thuiller W, Araújo MB, Martinez-Meyer E, Brotons L, McClean C, Miles L, Segurado P, Dawson TP, Lees DC (2006) Model-based uncertainty in species range prediction. J Biogeogr 33:1704-1711

Peterson AT (2011) Ecological niche conservatism: a time-structured review of evidence. J Biogeogr 38:817-827

Phillips SJ, Anderson RP, Schapire RE (2006) Maximum entropy modeling of species geographic distributions. Ecol Model 190:231-259

Pigot AL, Owens IPF, Orme CDL (2010) The environmental limits to geographic range expansion in birds. Ecol Lett 13:705-715
Qiao H, Soberón J, Peterson AT (2015) No silver bullets in correlative ecological niche modelling: insights from testing among many potential algorithms for niche estimation. Methods Ecol Evol 6:1126-1136

Quillfeldt P, Engler JO, Silk JRD, Phillips RA (2017) Influence of device accuracy and choice of algorithm for species distribution modelling of seabirds: a case study using black-browed albatrosses. J Avian Biol 48:1549-1555

Reif J, Št'astný K, Bejček V, (2010) Contrasting effects of climatic and habitat changes on birds with northern range limits in central Europe as revealed by an analysis of breeding bird distribution in the Czeck Republic. Acta Orn 45:83-90

Reside AE, VanDerWal JJ, Kutt AS, Perkins GC (2010) Weather, not climate, defines distributions of vagile bird species. PLoS ONE 5(10): 13569 . https://doi.org/10.1371/journal.pone.0013569

Scales KL, Miller PI, Ingram SN, Hazen EL, Bograd SJ, Phillips RA (2016) Identifying predictable foraging habitats for a wideranging marine predator using ensemble ecological niche models. Divers Distrib 22:211-224

Schidelko K, Stiels D, Rödder D (2011) Historical stability of diversity patterns in African estrildid finches (Aves: Estrildidae)? Biol J Linn Soc 102:455-470

Schidelko K, Wüstenhagen N, Stiels D, van den Elzen R, Rödder D (2013) Continental shelf as potential retreat areas for AustralAsian estrildid finches (Passeriformes: Estrildidae) during the Pleistocene. J Avian Biol 44:121-132

Serrano D, Oro D, Ursúa E, Tella JL (2005) Colony size selection determines adult survival and dispersal preferences: allee effects in a colonial bird. Am Nat 166:E22-E31

Soberón J, Peterson AT (2005) Interpretation of models of fundamental ecological niches and species' distributional areas. Biodivers Inform 2:1-10

Soroye P, Newbold T, Kerr J (2020) Climate change contributes to widespread declines among bumble bees across continents. Science 367:685-688

Strubbe D, Jackson H, Groombridge J, Matthysen E (2015) Invasion success of a global avian invader is explained by within-taxon niche structure and association with humans in the native range. Diversity Distrib 21:675-685

Thomas CD (2010) Climate, climate change and range boundaries. Diversity Distrib 16:488-495

Thomas CD, Lennon JJ (1999) Birds extend their ranges northwards. Nature. https://doi.org/10.1038/20335

Thuiller W (2003) Biomod - optimizing predictions of species distributions and projecting potential future shifts under global change. Glob Change Biol 9:1353-1362

Thuiller W, Lafourcade B, Engler R, Araújo MB (2009) BIOMOD - a platform for ensemble forecasting of species distributions. Ecography 32:369-373

Thuiller W, Münkemüller T, Schiffers KH, Georges D, Dullinger S, Eckhart VM, Edwards TC Jr, Gravel D, Kunstler G, Merow C, Moore K, Piedallu C, Vissault S, Zimmermann NE, Zurell D, Schurr FM (2014) Does probability of occurrence relate to population dynamics? Ecography 37:1-12

Thuiller W, Guégen M, Renaud J, Karger DN, Zimmermann NE (2019) Uncertainty in ensembles of global biodiversity scenarios. Nature Commun 10:1446. https://doi.org/10.1038/s41467-019-09519-w

Tingley MW, Monahan WB, Beissinger SR, Moritz C (2009) Birds track their Grinnellian niche through a century of climate change. Proc Nat Acad Sci 106:19637-19643

VanDerWal J, Shoo LP, Johnson CN, Williams SE (2009) Abundance and the environmental niche: environmental suitability estimated from niche models predicts the upper limit of local abundance. Am Nat. https://doi.org/10.1086/600087 
Veech JA, Smal MF, Baccus JT (2011) The effect of habitat on the range expansion of a native and and introduced bird species. $\mathbf{J}$ Biogeogr 38:69-77

Virkkala R, Lehikoinen A (2014) Patterns of climate-induced density shifts of species: poleward shifts faster in northern boreal birds than in southern birds. Global Change Biol 20:2995-3003

Voous KH (1960) Atlas van de Europese Vogels. Elsevier, Amsterdam Williams H, Willemoes M, Thorup K (2017) A temporally explicit species distribution model for a long distance avian migrant, the common cuckoo. J Avian Biol 48:1624-1636
Yosef R (2010) Thermoregulatory behavior in migratory European bee-eaters (Merops apiaster). Wilson J Ornithol 122:378-380

Zurell D, Graham CH, Gallien L, Thuiller W, Zimmermann NE (2018) Long-distance migratory birds threatened by multiple independent risks from global change. Nat Clim Chang. https://doi.org/10. 1038/s41558-018-0312-9

Publisher's Note Springer Nature remains neutral with regard to jurisdictional claims in published maps and institutional affiliations. 